\title{
Accidental Poisoning of a Child by Dieffenbachia
}

\author{
Bir Çocukta Kazara Difenbahya Zehirlenmesi
}

\author{
(1) Emel Ataş Berksoy ${ }^{1}$, (1) Ebru Topalakçı², (1) Özlem Bekem Soylu², (1) Tanju Çelik² \\ 1 University of Health Sciences, Tepecik Training and Research Hospital, Clinic of Pediatric Emergency, Izmir, Turkey \\ 2 University of Health Sciences, Dr. Behçet Uz Child Disease and Pediatric Surgery Training and Research Hospital, Clinic of Pediatrics, Izmir, Turkey
}

\section{Abstract}

Difenbahya evlerde süs amaçlı yetiştirilen tropikal bir bitkidir. Yaprak ya da tohumunun kazara çocuklar tarafından yenmesi acil tedavi gerektirecek ciddi gastrointestinal ve solunum sistemi bulgularına neden olabilir. Sekiz yaşında kız hasta acil servise ani başlayan dilde uyuşma, alt dudakta şişlik ve kızarıklık, konuşmada bozulma ve nefes almada zorluk yakınmaları ile başvurdu. Öyküsünden şikayetleri başlamadan beş dakika önce evde bulunan difenbahya bitkisinin toprağı ile kalemle oynadığı ve bu kalemi ağzına götürdüğü öğrenildi. Antihistaminik ve steroid tedavisi ile semptomlar geriledi. Ailelerin ve çocukların evlerde yaygın olarak kullanılan bu bitkinin yaşamı tehdit edici zehirlenme etkilerinden dolayı eğitilmesi çok önemlidir.

Anahtar Kelimeler: Çocuk, difenbahya, zehirlenme

\section{Öz}

Dieffenbachia is a tropical ornamental house plant. Accidental ingestion of the leaf or its seed can cause serious gastrointestinal and respiratory symptoms requiring emergency treatment. An eightyear-female child was admitted to the emergency department with sudden numbness on her tongue, lower lip swelling and redness, slurred speech and difficulty breathing. Upon further interview, it was revealed that five minutes prior to these symptoms occurred, the patient was playing with the soil of dieffenbachia with a pen and placing this pen in her mouth. Symptoms resolved after treatment with antihistamines and steroids. Training of families and children about toxic effects of Dieffenbachia which is widely used as a potted house plant is very important as chewing the plant results in lifethreatening consequences.

Keywords: Child, dieffenbachia, poisoning

\section{Introduction}

Dieffenbachia, commonly known as dumb cane, is a tropical ornamental house plant in the Araceae family and the Arum class (Figure 1). ${ }^{1}$ Although Dieffenbachia is aesthetically pleasing, it has life-threatening effects. Dieffenbachia causes severe local injuries to the tissues due to the oxalate crystals contained in the plant juice. When skin comes in contact with the plant oil, localized swelling, redness, burning, and pain can develop. If the plant is chewed, life-threatening systemic symptoms, such as respiratory failure, can occur. ${ }^{2}$

The case is presented to notify parents and children of the dangers of rare plant poisoning. Rare plants, such as
Dieffenbachia, can cause serious systemic, heart, lung, and neurological problems.

\section{Case}

An eight-year-old female, having no previously known diseases, was taken to the emergency department with sudden numbness in the tongue, lower lip swelling and redness, slurred speech, and difficulty breathing. Half an hour after arrival, the vital signs of the patient were stable (heart rate: 112 bpm, blood pressure: 100/65 mmHg, respiratory rate: 28/min, oxygen saturation: 96\%). All physical examination findings were normal except for swelling and redness of the

Address for Correspondence/Yazışma Adresi: Emel Ataş Berksoy MD, University of Health Sciences, Tepecik Training and Research Hospital, Clinic of Pediatric Emergency, İzmir, Turkey E-mail: emelberksoy@hotmail.com ORCID ID: orcid.org/0000-0002-6831-1353

Received/Geliş Tarihi: 18.07.2017 Accepted/Kabul Tarihi: 14.09.2017

${ }^{0}$ Copyright 2018 by Society of Pediatric Emergency and Intensive Care Medicine

Journal of Pediatric Emergency and Pediatric Intensive Care published by Galenos Yayınevi. 


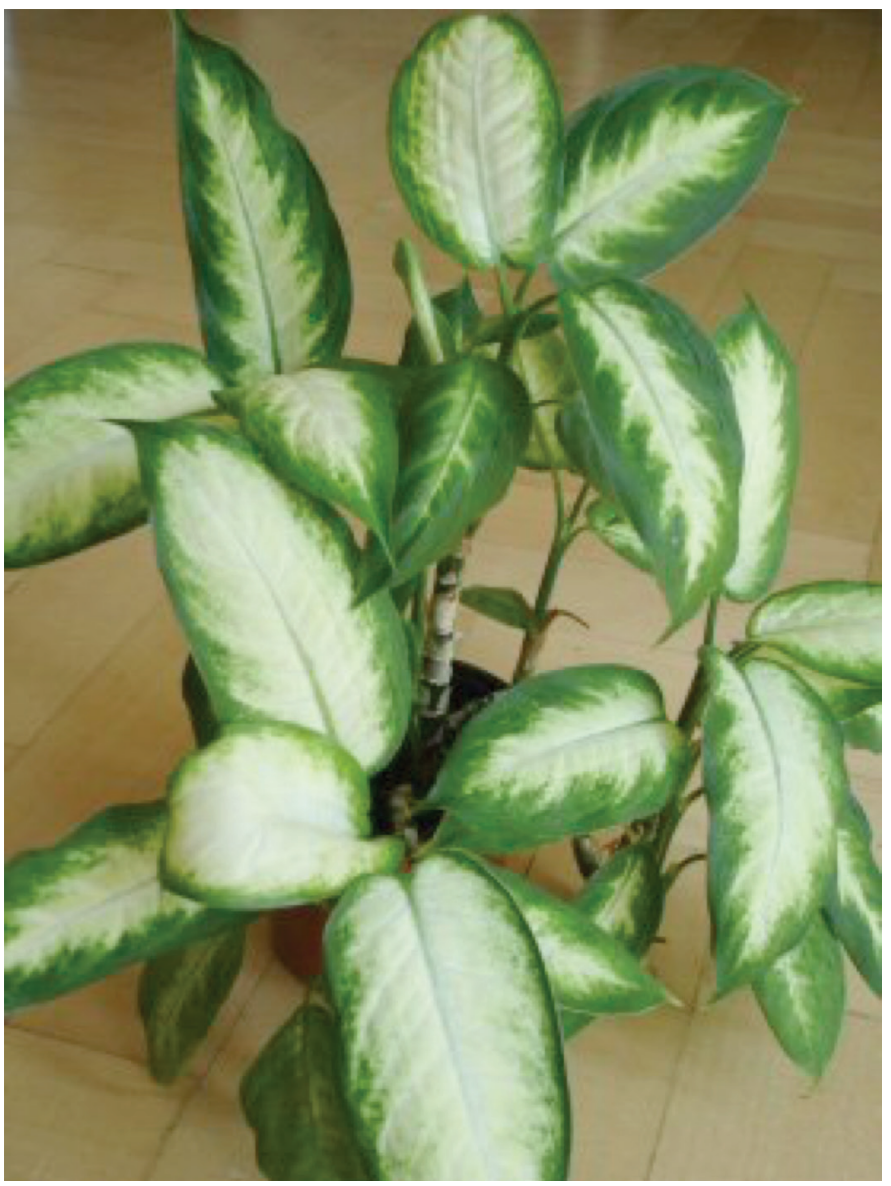

Figure 1. Dieffenbachia- camilla plant

lip and eye, and tongue numbness. The child was breathing with an open mouth and had slurred speech.

According to the mother, the patient was playing with soil from a dieffenbachia plant with a pen, and then she placed this pen in her mouth. This occurred five minutes before the symptoms began. The patient complained of tongue numbness, and given this complaint, plant poisoning was considered. Treatment with steroids and antihistamines (methyl prednisolone $1 \mathrm{mg} / \mathrm{kg}$, pheniramine $1 \mathrm{mg} / \mathrm{kg}$ ) was administered. Because of the sudden onset of complaints and respiratory distress, chest radiography was conducted to exclude the possibility of a foreign body aspiration. However, the results of this procedure were normal.

The patient was monitored, and her symptoms improved within two hours after treatment. The initial plan was to closely monitor the child in the emergency department for 24 hours to ensure that airway obstruction or dyspnea did not develop due to the toxic effects of Dieffenbachia. However, after 24-hours of observation, the child made a full clinical improvement. The patient was discharged after she and her family were informed about plant poisoning.

\section{Discussion}

Dieffenbachia is a tropical ornamental houseplant that is imported from the American tropics. The plant has a known toxicity dating back to the late $17^{\text {th }}$ century. Natives living in the Amazon used it as arrow poison, and they would also drop the plant's oil into the mouths of slaves as a form of torture. Although the precise toxicity mechanism is unknown, calcium oxalate crystals (raphides) and protease in the idioblast of the plant are considered to be the causes. The raphides and proteolytic enzymes in leaves cause irritation and inflammation if the leaves are torn by hand or chewed. Clinical findings can occur with ocular, skin, and oral contact. Severe pain, chemosis, blepharospasm, photophobia, lacrimation, corneal abrasions, and keratoconjunctivitis may develop with ocular contact. Dermatitis, burns, or bullous eruption can be seen with dermal contact. After oral intake, pain, edema, an increase in secretions, ulceration, vomiting, diarrhea, and dysphagia may develop. ${ }^{1}$ In Turkey, Şişmanlar et al. ${ }^{3}$ reported a case where a three-year-old child who ingested leaves from the plant developed clinical findings similar to those discussed in our case. ${ }^{3}$

In another case, an adolescent ate the plant in a suicide attempt. The adolescent subsequently developed severe airway obstruction requiring a tracheotomy due to esophagitis secondary to an aorta-esophageal fistula. ${ }^{4}$ Dieffenbachia poisoning cases have also been published in the veterinary literature. One case involved a dog that died from a severe airway obstruction due to glottic edema that manifested after eating the plant. ${ }^{5}$ Another case involved a cat that developed a severe gastric ulcer. ${ }^{6}$

In Dieffenbachia poisoning, symptoms often develop within the first five minutes and resolve with minimal supportive treatment. In our case, the symptoms developed within the first few minutes after contact. While cold applications and analgesics are sufficient to treat those with local findings, treatment with antihistamines and steroids is preferred to treat those with systemic findings.

The symptoms and findings in our patient responded well to treatment, and there were no complications during the 24-hour follow-up period. Intubation and tracheostomy may be required in patients with severe respiratory distress. The severity of symptoms may be correlated with the amount of plant intake, as increased plant ingestion may cause airway obstruction and subsequent complications.

\section{Conclusion}

Plant poisoning, although rare, should be considered for a diagnosis in children when the symptoms of angioedema and/or sudden onset of airway obstruction are present. Dieffenbachia is a common decorative plant in homes, thus, 
it is critical to educate families and children about its lifethreatening poisonous effects.

\section{Ethics}

Informed Consent: Written informed consent was taken from the parents for reporting this case.

Peer-review: Externally and internally peer-reviewed.

\section{Authorship Contributions}

Surgical and Medical Practices: E.A.B., Concept: E.A.B., Design: E.A.B., Data Collection or Processing: E.T., Analysis or Interpretation: Ö.B.S., Literature Search: T.Ç., Writing: E.A.B. Conflict of Interest: No conflict of interest was declared by the authors.

Financial Disclosure: The authors declared that this study received no financial support.

\section{References}

1. Cumpston KL, Vogel SN, Leikin JB, Erickson TB. Acute airway compromise after brief exposure to a Dieffenbachia plant. J Emerg Med. 2003;25:391-7.

2. Dip EC, Pereira NA, Fernandes PD. Ability of eugenol to reduce tongue edema induced by Dieffenbachia picta Schott in mice. Toxicon. 2004;43:729-35.

3. Şişmanlar T, Onganlar YH, Derinöz O, Kula S, Kanbur ŞM, Vuralli D. Evdeki Yeşil Tehlikeler "Difenbahya Zehirlenmesi". Gazi Medical Journal. 2010;21:51-2.

4. Snajdauf J, Mixa V, Rygl M, Vyhnánek M, Morávek J, Kabelka Z. Aortoesophageal fistula-an unusual complication of esophagitis caused by Dieffenbachia ingestion. J Pediatr Surg. 2005;40:e2931.

5. Loretti $A P$, da Silva Ilha $M R$, Ribeiro RE. Accidental fatal poisoning of a dog by Dieffenbachia picta (dumb cane). Vet Hum Toxicol. 2003;45:233-9.

6. Müller N, Glaus T, Gardelle O. [Extensive stomach ulcers due to Dieffenbachia intoxication in a cat]. Tierarztl Prax Ausg K Kleintiere Heimtiere. 1998;26:404-7. 